\title{
Increased Dose-Response Relationship of Liver Plasma Membrane Adenylate Cyclase to Glucagon Stimulation in Diabetic Rats. A Possible Role of the Guanyl Nucleotide-Binding Regulatory Protein
}

\author{
H. Allgayer, W. Bachmann, and K. D. Hepp \\ Diabetes Research Unit, City Hospital München-Schwabing, Munich, FRG
}

Summary. In view of controversial findings regarding the mechanism for the increased intracellular hepatic cyclic $3^{\prime}: 5^{\prime}$ adenosine monophosphate levels in diabetic rats, we studied the dose-response relationship of the adenylate cyclase to glucagon stimulation in severely diabetic and in diabetic, insulin-treated rats. An enhanced response to glucagon and an additional augmenting effect of guanosine triphosphate on hormonal stimulation of the adenylate cyclase activity were found in diabetes which were reversible with insulin treatment. The results suggest a role of the regulatory guanyl nucleotide-binding protein in diabetes leading to an increased dose response relationship of the hepatic adenylate cyclase system to glucagon.

Key words: Streptozotocin diabetes, glucagon stimulation, adenylate cyclase dose response relationship, stimulatory effect of guanosine triphosphate, guanyl nucleotide-depending regulatory protein.

Elevated tissue $3^{\prime}: 5^{\prime}$ cyclic adenosine monophosphate levels have been reported to occur in livers and fat cells of diabetic rats and mice [1, 2]. A similar increase has been found in livers of fasted animals $[3,4]$. The mechanisms involved in these effects are thought to be decreased cyclic AMP degradation due to lowered phosphodiesterase activity $[2,3]$ and/or activation of the adenylate cyclase system. With respect to the cyclase system the acute activation could be due to changes in the insulin-glucagon ratio [5] and an increased sensitivity to glucagon could be involved. The latter was shown in crude membrane fractions from livers of streptozotocin-diabetic mice [6]. After treatment with insulin this increased sensitivity to glucagon stimulation returned to normal values [6]. In contrast Pilkis et al. found no difference in hormonal stimulation of the adenylate cyclase system in both diabetic and non-diabetic control animals [2]. This discrepancy prompted us to re-investigate the change in sensitivity of the adenylate cyclase to glucagon in diabetic rats and the effects of insulin treatment with special reference to the action of guanyl nucleotides.

\section{Materials and Methods}

\section{Hormones and Chemicals}

Streptozotocin- $\mathrm{HCl}$ was provided by the Upjohn Company, Heppenheim, FRG; unlabelled glucagon was purchased from Novo, Copenhagen, Denmark; insulin preparations from Hoechst, Frankfurt, FRG. Human albumin was obtained from the Swiss Red Cross, Berne, Switzerland; $\alpha-\mathrm{P}^{32}$-adenosine triphosphate was supplied by the Radiochemical Centre, Amersham, UK with a specific activity of $8-10 \mathrm{Ci} / \mathrm{mmol}$ in a water-ethanol mixture $(1: 1)$; beef pork ${ }^{125} \mathrm{I}$ glucagon (specific activity $150-200 \mathrm{Ci} / \mathrm{g}$ ) was from Cambridge Nuclear Radiopharmaceutical Corporation, Billerice, Mass, USA; all other chemicals were of analytical grade and obtained from commercial sources.

\section{Animals}

Male Wistar rats from Ivanovas, Kisslegg, FRG were used and fed a commercial diet (Altromin, Lage-Lippe, FRG) with free access to tap water. The rats were sacrificed after an overnight fast.

\section{Experimental Procedure}

Animal treatment: Experimental diabetes was induced by IV injection of $100 \mathrm{mg} / \mathrm{kg}$ streptozotocin- $\mathrm{HCl}$ (dissolved in $0.154 \mathrm{~mol} / 1$ $\mathrm{NaCl}, \mathrm{pH} 4$ ) to rats weighing $120-150 \mathrm{~g}$. A first group of diabetic animals $(n=18)$ received no treatment over a period of 6 days, a second group of rats $(n=12)$ was treated with insulin (Depot Hoechst CR) twice daily ( $8 \mathrm{IU}$ at $8.00 \mathrm{~h}, 10 \mathrm{IU}$ at $20.00 \mathrm{~h} \mathrm{SC}$ ) for 3 days after a duration of diabetes of 6 days. Six of 18 diabetic animals died in diabetic coma with acetonuria, exsiccosis and hyperventilation. A third group $(n=9)$ served as non-diabetic controls and received identical volumes of saline instead of streptozotocin. 
Plasma membrane isolation: Liver plasma membranes were prepared according to a modified method of Neville and Ray as described in detail elsewhere [7]. Two to five livers were used for one preparation.

Assay procedures: The purity and contamination of the membranes were checked by 5'nucleotidase [8], Mg-ATPase [9], alkaline phosphatase [9], glucose-6-phosphatase [10] and succinate-INT-reductase [11]. Protein was determined with a modified method described by Lowry et al. [12], using bovine albumin as standard. Plasma glucose levels were measured with the hexokinase method [12], insulin levels were determined as immunoreactive insulin using a rat insulin standard [14], glucagon concentrations as immunoreactive glucagon $[14,15]$.

Binding studies: Binding of insulin and glucagon to the membranes was determined as described previously [15]. All binding data were corrected for non-specific binding, which has been shown to be in the range of $3 \%-10 \%$.

Adenylate cyclase assay: Adenylate cyclase activity was measured following a modified method described by Salomon et al. [16] with non-radioactive cyclic AMP as a 'trapping system'. This 'trapping system' leads to similar results as a mixture containing the phosphodiesterase inhibitor isobutylmethylxanthine. The assay mixture consisted of $\mathrm{MgCl}_{2}(5 \mathrm{mmol} / \mathrm{l})$, radioactive cyclic AMP $(1 \mathrm{mmol} / \mathrm{l})$, albumin $(0.1 \%)$, EDTA $(1 \mathrm{mmol} / 1)$, an ATP regenerating system: creatine phosphate $(10 \mathrm{mmol} / \mathrm{l})$ and creatine-phosphokinase $(0.3 \mathrm{mg} / \mathrm{ml}), \alpha^{32} \mathrm{P}$ ATP $(300000-600000 \mathrm{cpm}$, dissolved in non-radioactive ATP $(0.45 \mathrm{mmol} / \mathrm{l})), \mathrm{NaF}(10 \mathrm{mmol} / \mathrm{l})$ or glucagon in concentrations as indicated in the experiments, guanosine triphosphate as indicated and membranes in a concentration of $0.07-0.1 \mathrm{mg} / \mathrm{ml}$ in a total volume of $0.1 \mathrm{ml}(\mathrm{pH} 7.4)$. Incubation was stopped after $10 \mathrm{~min}$ at $37^{\circ} \mathrm{C}$ and separation of newly formed ${ }^{32} \mathrm{P}$ cyclic AMP was performed on Dowex and aluminium hydroxide columns [16]. The activity was expressed as nmol $\mathrm{g}^{-1} \mathrm{~min}^{-1} \mathrm{calcu}-$ lated from a computerized programme (Olivetti programma 101). The assay system showed linearity both with respect to amount of membrane protein used and incubation time.

Statistical calculations were performed using Student's t-test for unpaired or where applicable, paired comparison. $p$ levels $<0.05$ were considered as significant.

\section{Results}

Within 6 days after streptozotocin injection $(100 \mathrm{mg} /$ $\mathrm{kg}$ ), the animals developed severe diabetes with blood glucose levels in the range of $22 \mathrm{mmol} / 1$ and ketonuria.

Plasma insulin levels decreased from $9.8 \pm 3.1$ to $4.3 \pm 2.9 \mathrm{mU} / 1(p<0.01)$ while plasma glucagon rose from $39.1 \pm 11.0$ to $60.3 \pm 20.3 \mathrm{pmol} / 1(p<$ 0.01 ) in the diabetic group (mean \pm SD). Hepatic plasma membranes from control, diabetic and diabetic, insulin-treated animals revealed no major differences in the enzyme markers 5'nucleotidase, $\mathrm{Mg}^{2+}$ ATPase, succinate-INT-reductase, alkaline phosphatase and glucose-6-phosphate dehydrogenase. With a concentration of ${ }^{125}$ I-glucagon of $143 \mu \mathrm{mol} / \mathrm{l}$ in the in- cubation medium, a $60 \%$ decrease in the binding of glucagon was found [control $(n=16): 85.7 \pm 25.7$; diabetic rats $(n=17): 28.5 \pm 20.0 \mathrm{pmol} / \mathrm{g}$ membrane protein $\left(n=16\right.$ ]. The binding of ${ }^{125} \mathrm{I}$-insulin at a concentration of $0.67 \mathrm{nmol} / 1$, on the other hand, was increased in diabetes by $60 \%$ [control $(n=16): 0.15 \pm$ 0.02 ; diabetic rats $(n=17): 0.26 \pm 0.02 \mathrm{pmol} / \mathrm{g}$ of membrane protein, mean \pm SD]. Both differences were statistically significant $(p<0.01)$.

As shown in Figure 1, the dose-response relationship for glucagon stimulation of the hepatic adenylate cyclase was significantly increased compared with controls. This effect was observed with glucagon concentrations as low as $7 \times 10^{-8} \mathrm{~mol} / \mathrm{l}: 280 \pm 13$ in diabetes versus $200 \pm 10 \mathrm{nmol} / \mathrm{g}^{-1} \mathrm{~min}^{-1}$ in controls (mean $\pm \mathrm{SEM}, p<0.01$ ) and was more pronounced at maximal stimulation $7 \times 10^{-7} \mathrm{~mol} / \mathrm{l}: 379 \pm 32$ in diabetes versus $256 \pm 94 \mathrm{nmol} \mathrm{g}^{-1} \mathrm{~min}^{-1}$ in controls $(p<0.01)$. The basal and the fluoride stimulated activity remained unchanged (Table 1). In contrast to the elevated enzyme activities in diabetes, the affinity of the adenylate cyclase to glucagon was decreased by $44 \%: \mathrm{K}_{\mathrm{a}}$ diabetes: $9.68 \times 10^{-8}$ versus $\mathrm{K}_{\mathrm{a}}$ control: 5.43 $\pm 10^{-8} \mathrm{~mol} / \mathrm{l}$, as calculated from a Lineweaver-Burk diagram.

An additional stimulating effect of GTP $\left(10^{-4}\right.$ $\mathrm{mol} / \mathrm{l})$ to glucagon response in control rats was measured at glucagon concentrations of $7 \times 10^{-9} \mathrm{~mol} / \mathrm{l}$ and reached its maximum at glucagon concentrations of $7 \times 10^{-7} \mathrm{~mol} / 1 \mathrm{l}(386 \pm 10$ versus $256 \pm 94 \mathrm{nmol}$ $\mathrm{g}^{-1} \min ^{-1}, \mathrm{p}<0.01$ ), corresponding to an 1.5 -fold additional stimulation of the maximal glucagon effect (Fig. 2, Table 1). This GTP induced additional stimulation of the effect of glucagon was even more pronounced in diabetes (Fig. 2) with maximal stimulation at $7 \times 10^{-7} \mathrm{~mol} / \mathrm{l}: 845 \pm 168$ in the presence versus $379 \pm 32 \mathrm{nmol} \mathrm{g}{ }^{-1} \mathrm{~min}^{-1}$ in the absence of $10^{-4}$ mol $/ 1$ GTP ( $p<0.02$, mean \pm SEM); thus, GTP causes a 2.2-fold additional effect in diabetes compared with only a 1.5 -fold stimulation in the control rats (Table $1 ; p<0.02$ ).

In order to study the changes of the hormonal responsiveness of the adenylate cyclase after insulin treatment, severly diabetic rats (streptozotocin $100 \mathrm{mg} / \mathrm{kg}$ ) were treated with insulin for 3 days. A return to near-normal glucose levels was obtained. Four insufficiently treated animals with glucosuria and/or ketonuria were excluded from this group. The additional increase in stimulation of the adenylate cyclase in the presence of added GTP returned to almost normal values after insulin treatment with a dose response relationship as shown in Figure 2. The glucagon stimulation in the absence of added GTP, however, remained at the same level as observed in untreated diabetes $\left(378 \pm 62\right.$ versus $379 \pm 32 \mathrm{nmol} \mathrm{g}^{-1}$ 


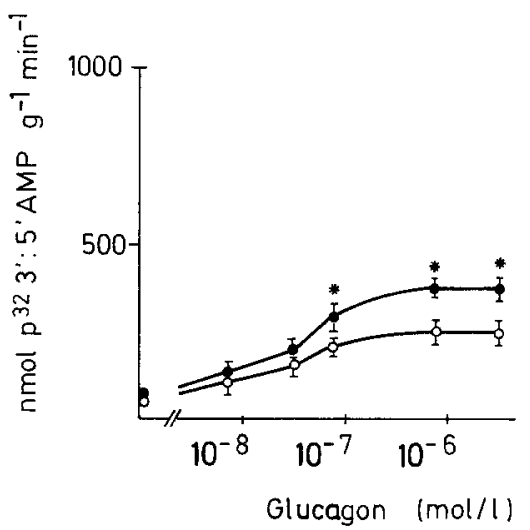

Fig. 1. Dose-response relationship of the adenylate cyclase activity from liver plasma membranes of diabetic ( $-\mathbf{C})$ and control rats $(\mathrm{O}-\mathrm{O})$. Each point represents the mean \pm SEM of three to ten separate membrane preparations. ${ }^{*} p<0.01$

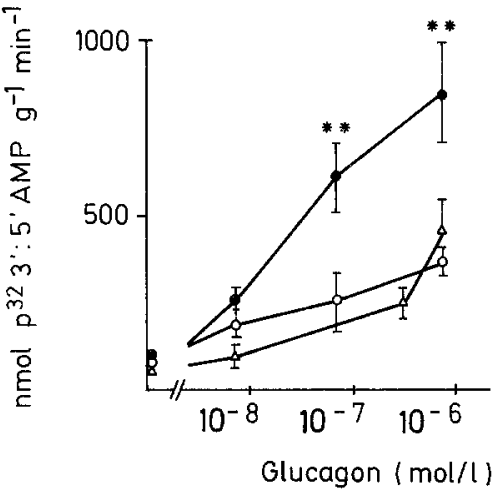

Fig. 2. Dose-response relationship of the adenylate cyclase activity from liver plasma membranes of diabetic (-O), insulintreated $(\Delta-\Delta)$ and control rats $(O-O)$ in the presence of $10^{-4} \mathrm{~mol} / 1 \mathrm{GTP}$ in the reaction medium. Results are expressed as mean \pm SEM of three to six separate membrane preparations. ** $p$ $<0.02$ (diabetic versus control rats and versus insulin treatment)

Table 1. Comparison of basal, glucagon, glucagon + guanosine triphosphate and sodium fluoride stimulated adenylate cyclase activities in liver plasma membranes from diabetic, insulin-treated diabetic, and control rats ( $\overline{\mathrm{x}} \pm \mathrm{SEM}, 3-10$ membrane preparations)

\begin{tabular}{|c|c|c|c|c|c|c|}
\hline & \multicolumn{6}{|c|}{ Adenylate cyclase activity $\left(\mathrm{nmol}^{-1} \mathrm{~min}^{-1}\right)$} \\
\hline & $\begin{array}{l}\text { Control rats } \\
\text { A }\end{array}$ & $\begin{array}{l}\text { Diabetic rats } \\
\text { B }\end{array}$ & $\begin{array}{l}\text { Diabetic rats } \\
\text { (insulin-treated) } \\
\text { C }\end{array}$ & $\begin{array}{l}p \\
\text { A versus B }\end{array}$ & B versus $\mathrm{C}$ & $\begin{array}{l}p \\
\text { C versus A }\end{array}$ \\
\hline Basal values & $54 \pm 17$ & $56 \pm 15$ & $42 \pm 12$ & NS & NS & NS \\
\hline Glucagon $\left(7 \times 10^{-7} \mathrm{~mol} / \mathrm{l}\right)$ & $256 \pm 94$ & $379 \pm 32$ & $378 \pm 61$ & $<0.01$ & NS & $<0.02$ \\
\hline $\begin{array}{l}\text { Glucagon } \\
\left(7 \times 10^{-7} \mathrm{~mol} / \mathrm{l}\right)+\mathrm{GTP}\left(10^{-4} \mathrm{~mol} / \mathrm{l}\right)\end{array}$ & $386 \pm 10$ & $845 \pm 168$ & $448 \pm 90$ & $<0.02$ & $<0.05$ & NS \\
\hline $\mathrm{NaF}(10 \mathrm{mmol} / \mathrm{l})$ & $428 \pm 42$ & $498 \pm 90$ & $349 \pm 76$ & NS & NS & NS \\
\hline
\end{tabular}

Ns = not significant

$\min ^{-1}$. Basal and fluoride stimulated activities were not altered throughout all experiments (Table 1).

\section{Discussion}

In this study we have extended our earlier observation of an increased hepatic adenylate cyclase sensitivity to glucagon in diabetes using crude membrane fractions from mouse liver [6] to hepatic plasma membranes in rats. Reversibility of the additional GTP stimulation was reached after insulin treatment. The results are in contrast to those of Pilkis et al. [2], who could not demonstrate any differences in the hormonal response under diabetic conditions. These variations could be due to different severity of diabetes, since in a milder form of diabetes induced by streptozotocin $(80 \mathrm{mg} / \mathrm{kg})$ we found, like Pilkis et al. [2], no difference in both groups (unpublished data). These variant results could also be due to differences in membrane isolation techniques.

The enhanced dose response relationship in untreated diabetes and the increased additional GTP response leads to the question of which step of the adenylate cyclase system may be activated in diabetes. The adenylate cyclase system appears to consist of at least three separate components [17]: a hormonal receptor specific for a certain hormone on the outside of the membrane, a catalytic unit catalyzing the conversion of ATP to cyclic AMP and a guanyl nucleotidebinding regulatory protein, called $\mathrm{G} / \mathrm{F}$ or $\mathrm{N}$ protein [18]. This $N$ unit has been shown to be responsible for the hormonal, GTP and fluoride stimulated activities of liver adenylate cyclase $[18,21]$ with a localisation most probably at the inner surface of the plasma membrane [19]. One essential component of this multi-subunit $N$ protein is the GTP binding site $[21,25]$. The GTP-N protein complex formed after reaction 
and dissociation of the hormone-receptor complex is believed to be the only stimulator of the adenylate cyclase [17, 22]. The activity of the $\mathrm{N}$ protein is associated with a GTPase $[22,23]$ and/or the release of tightly bound inhibitory GDP from the $\mathrm{N}$ unit [25]. A possible modulation of the $\mathrm{N}$ unit activity may be the decreased GTPase activity as shown for the cholera-toxin-dependent enhancement of the GTP effect on the adenylate cyclase [17,18]. This effect was shown to be directly correlated with a cholera-toxindependent ADP ribosylation of the N unit [24]. Our results suggest that a step beyond the receptor, most probably an activation of the $\mathrm{N}$ unit may be involved in the enhanced dose response relationship for glucagon of the adenylate cyclase in severe diabetes, since this effect was augmented in the presence of GTP.

Acknowledgements. We thank Drs. I. Böttger and W. Gerbitz for the determination of insulin and glucagon levels and acknowledge the skillful technical assistance of Mrs. A. Melzer.

\section{References}

1. Jefferson SL, Exton JH, Butcher RW, Sutherland EW, Park CR (1968) Role of adenosine $3^{\prime}: 5^{\prime}$ monophosphate in the effects of insulin and anti-insulin serum on liver metabolism. $J$ Biol Chem 243: 1031-1038

2. Pilkis SJ, Exton JJ, Johnson RH, Park CR (1974) Effects of glucagon on cyclic AMP and carbohydrate metabolism in liver from diabetic rats. Biochem Biophys Acta 343:250-267

3. Exton JH, Park CR (1968) Control of gluconeogenesis in liver. J Biol Chem 243: 4188-4196

4. Lavine RL, Voyles N, Recant L, Perrino PV (1975) The effect of fasting on tissue cyclic AMP and plasma glucagon in the obesehyperglycemic mouse. Endocrinology 91: 115-120

5. Unger RH, Orci D (1975) The essential role of glucagon in the pathogenesis of diabetes mellitus. Lancet 1:14-16

6. Hepp KD (1972) Adenylate cyclase and insulin action. Eur J Biochem 31:266-276

7. Bachmann W, Harms E, Hassels B, Henninger HP, Reutter W (1977) Studies in rat liver membrane. Biochem J 166:455-463

8. Mitchell RH, Hawthoren JN (1965) The site of diphosphoinositol synthesis in rat liver. Biochem Biophys Res Comm 214: 335-338

9. Emmelot P, Bos CJ (1962) Studies on plasma membranes of rat liver. Biochim Biophys Acta 120:369-382

10. de Duve C, Pressman BC, Garetta R, Wattiaux R, Applemans F (1955) Glucose-6-phosphatase, isolation and preparation. Biochem J 60: 604-671
11. Pennington F (1961) Biochemistry of dystrophic muscle mitochondrial succinate tetrazolium reductase and adenosine triphosphatase. Biochem J 80: 649-754

12. Lowry OH, Rosebrough NG, Farr AL, Randall RJ (1951) Determination of protein with the folin reagent. J Biol Chem 193: 265-275

13. Schmidt F (1961) Die enzymatische Bestimmung von Glucose und Fructose nebeneinander. Klin Wschr 39: 1244-1247

14. Unger RH, Aguillar-Parada E, Müller WA, Eisentraut AH (1970) Studies on pancreatic alpha cell function in normal and diabetic subjects. J Clin Invest 49:837-846

15. Bachmann W, Böttger J, Haslbeck M, Mehnert H (1979) Extrapancreatic action of sulphonylureas: effects of gliquidon on insulin and glucagon binding to rat liver plasma membranes. Eur $\mathrm{J}$ Clin Invest 9: 411-415

16. Salomon G, Londos G, Rodbell M (1974) A highly sensitive assay of adenylate cyclase. Analyt Biochem 58: 541-548

17. Ross EM, Gilman AJ (1980) Biochemical properties of hormone sensitive adenylate cyclase. Ann Rev Biochem 49: 533-564

18. Rodbell M (1980) The role of hormone receptors and GTP regulatory proteins in membrane transduction. Science 284: 17-22

19. Farfel Z, Kaslow HR, Bourne HR (1980) A regulatory component of adenylate cyclase is located on the inner surface of human erythrocyte membrane. Biochem Biophys Res Comm 90: $1237-1241$

20. Pfeuffer T (1977) GTP-binding proteins in membranes and the control of adenylate cyclase activity. J Biol Chem 252: $7224-7234$

21. Kaslow HR, Johnson GL, Brother VM, Bourne HR (1980) A regulatory component of adenylate cyclase from human erythrocyte membranes. J Biol Chem 255:3736-3741

22. Cassel D, Levkovitz H, Selinger Z (1977) The regulatory GTPase cycle of turkey erythrocyte adenylate cyclase. J Nucl Res 3:393-404

23. Pike LJ, Levkovitz HJ (1980) Activation and desentization of $\beta$-adrenergic receptor coupled GTPase and adenylate cyclase of frog and turkey erythrocyte membranes. J Biol Chem 255: $6860-6867$

24. Gill DM, Meren R (1978) ADP ribosylation of membrane proteins catalyzed by cholera toxin, basis of activation of adenylate cyclase. Proc Natl Acad Sci USA 75:3050-3054

25. Nielsen ThB, Lach PM, Preston MS, Kempner E, Schlegel W, Rodbell M (1981) Structure of the turkey erythrocyte adenylate cyclase system. Proc Natl Acad Sci USA 78 (2): 722-726

Received: 6 July 1981

and in revised form: 15 February 1982

Dipl. Biol. Dr.med. H.Allgayer

II. Medizinische Klinik

Klinikum Großhadern

Ludwig-Maximilians-Universität München

Marchioninistr. 15

D-8000 München 70, FRG 